\title{
Humor and creativity: Poetry about libraries
}

\author{
By Norman D. Stevens
}

Director
The Molesworth Institute

Library poetry is surely a term that can best be described as the ideal oxymoron. An exhaustive Boolean search, using the terms "library" and poetry," in virtually every online public access catalog in major American academic libraries, online databases, and even all CD-ROM products has failed to turn up a single appropriate match for those two distinctly unrelated terms. There were a number of false leads that turned out invariably to be only articles or books about poems and poetry in libraries not about libraries. A true match (e.g., poems and poetry about libraries) may be an example of the only two terms not represented by a single link in any of those sophisticated searching systems.

That is not to say that there is not a large quantity of what passes-or more accurately barely slips by-as "library poetry." That can, however, best be described as something to do with libraries that is printed in a form that appears at first glance to be poetry. Upon closer examination such pieces invariably turn out to be merely verse, jingles, or more often doggerel; and that is only if one is being extremely charitable. Libraries may sustain poets but they seldom inspire them to "place the best words in the best order," as Coleridge put it, to sing our praises. Perhaps only Karl Shapiro's poem "Libraries" "Libraries, where one takes on the smell of books, stale and attractive. Service with no motive, simple as the U.S. Mail..." [Collected Poems 1940-1978, p. 209]) can be said to be a recognized poem about libraries by a major poet. Otherpieces, such as Calvin Trillin's recent paean, "The Man Who Saved the Library: An Ode to Vartan Gregorian," that appeared in the New York Times Book Review, are simply more doggerel (“...And, finishing a fourteen-hour day/Gregorian was often heard to say/'Hey look-I'm having fun. I'm having a blast.'/He was-presiding over this vast cast...").

Utterly rejected by all major, and even most minor, poets, librarians have had to turn to creating their own verse to celebrate their own accomplishments; most of what we have churned out is far worse than anything Trillin could have concocted. The largest proportion of our locally produced poetry may be charitably described as bad poetry and, luckily, seldom sees the light of day although first the photocopy machine and now the personal computer have made its dissemination a greater hazard to our mental health than ever before. Local library poetry is most often produced by the resident poet, and/or social organizer, on holidayswhen our guard is down - or most often when a beloved staff member is leaving either to accept a position elsewhere-where she may hope to escape such creations in the future-or to retire to a tranquil life free from well-meaning colleagues. Those creations are most often adaptations or parodies of well-known poems, or songs, for which words thought to fit the rhyme scheme and/or music and alleged to be appropriate for the occasion have been supplied. My research reveals that there are more library versions of "A Visit from St. Nicholas" (closely followed by "The Twelve Days of Christmas") than of any other poem and that the majority of those deal with the flaws in a particular library's technical services operations ("Twas the night before Christmas and all through $\mathrm{TS}$,/Not a

\section{Feeling funny?}

Where do we go from here? Why don't you tell me. Virtually every possible topic I have suggested, with the possible exception of the dreaded staff refrigerator, that I might comment on, I have now commented on. Your thoughts on possible topics for future pieces, preferably accompanied by appropriate examples, would be most welcome. They might even eventually result in a piece on your favorite subject that includes mention of your work or that of your colleagues. Even if you don't respond, though, I have ample material on hand, and more drifts in regularly, for me to concoct some additional pieces on other oddities of contemporary academic librarianship. Still keep those cards and letters coming to Norman D. Stevens, 143 Hanks Hill Road, Storrs, CT 06268 . 
creature was stirring, the place was a mess./The backlogs were piled in numbers so great, $/ \mathrm{We}$ feared that the floors would be cracked by their weight...." from "A Tech Service Christmas" by Alan Arnold, first published in The Library Muse from the University of Missouri Library). Even those library "poems" that seem apt and skillfully crafted when first heard at a party, especially when some of us have had a bit too much of the wine punch, seldom pass the test of time even when measured by the simple 24-hour reflective examination. They are all soon happily forgotten, even by their creator.

There are, of course, a few exceptions. Libraries have had a long history of providing shelter and sometimes employment for eccentric and creative souls and, from time to time, one of those souls emerges as a poet who produces one or more poems that are well-crafted, entertaining, and worth remembering and reciting. Historically it seems to have been the large city public library that was most hospitable to such creative persons as represented, for example, by William Fitch Smyth (1857-1940), who worked for many years as an evening desk attendant in the Cleveland Public Library where he presided as the resident poetlaureate. In 1910 he produced a small hand-lettered pamphlet, Little Lyrics for Librarians, that contains the best of his work, including "A Librarian's Life" ("A librarian's life is the life for me/For there's nothing at all to do, you see,/But to sit at a desk and read new books, /And admire yourself, and think of your looks./To questioning souls one can tartly say: 'I can't be bothered with you to-day,' For I haven't finished this novel. See?'A librarian's life is the life for me."). In more recent years it appears as though academic libraries have become the more frequent haven for creative types often in the form of one-time, or even sometime, students who have wanted to remain in the academic environment and may have joined the library, often in a support position, that provides them with a secure, if not lucrative, living, a chance to retain an affiliation with a seat of learning, and ample opportunity for them to exercise their creative talents that sometimes takes the form of poetry about libraries.

My appeals for examples of library poetry, good or bad, that appeared as an adjunct to the earlier pieces in this series have brought me, either directly or indirectly, a fairly large number of pieces. Some of that, unfortunately, has even been created in response to my mistaken plea. Most of it is little more than doggerel and deserves to be forgotten or at least safely buried in my archives for some future historian of library poetry who may be brash enough to compile, but not publish, the definitive collection of such stuff.

With due warning to the cautious or timid reader to cease now, I venture to offer only a few examples of recent library poetry that seem to have some merit at least in so far as any piece of library poetry can be said to have merit. These pieces, in any case, do provide us with a few chuckles, a smile, or even a moment of thoughtful reflection.

Perhaps the most frequent creative use of library poetry, intentionally humorous, is at the Owen Science and Engineering Library at Washington State University where, for a number of years, such efforts have been used as a part of a planned public relations campaign. Examples of that work, which includes such traditional aims as maintaining silence ("The sound of silence we demand./If you're a scholar, you understand./... If you talk, you walk./ We'll give no reprieve-/You'll be asked to leave."), can be found in Elizabeth P. Roberts" article, "Wit and Wisdom in the Library; or Public Relations, a New Twist" (PNLA Quarterly 53 (Winter 1989): 31-33).

In response to my quest for library poetry, the staff of the Acquisitions Department at the University of Illinois - thanks to some arm twisting by their boss Karen Schmidt--produced a veritable spate of verse that was published in their departmental newsletter. Much of that deals, naturally, with the arcane innerworkings of academic libraries ("The title page is sacred!/Each clerk in the library knows,/You never mark on the title page,/It only causes woes....") and best remains where it is.

All of my best efforts to date have turned up only two serious library poets, or at least two library poets who deserve to be taken seriously, not including Alan Arnold who continues to churn stuff out (“...Guide your servant OCLC,/Let its wisdom ne'er be smited./Deliver us from greedy men,/ Who'd have its data copyrighted," from "A Prayer for Technical Services") that sometimes catches our fancy.

Anita Norman, of the Kearney State College Library, is a poet who works in a library and sometimes write poems that deal with libraries. Her poetry is serious creative work that speaks to the realities of life in the academic library. One of her several librarypoems, "College Library," is printed below with her permission.

Our best contemporary library poet, though, may well be the elusive Esme Peabody, librarian at the Hubert W. Woodbine Library for Enigmatic Studies, whose poems have appeared in Vacuum Cleaner World, Flatbeat Magazine, and Ladies Home Journal. In an interview in the July 28,1988 , issue of General News, the staff newsletter of the General Libraries at Emory University, Peabody offered many enlightening comments about her work (as "she welcomed us with a languid wave of her long ink-stained fingers") and life. In response, for example, to a question as to whether many of her poems are about libraries, Peabody allowed that "working in a library can have a certain influ- 
ence on one's imagery, but...no, only one poem has really had anything to do with libraries. I shall do my best to see that it doesn't happen again, but I'm making no promises." Fortunately that single library poem, which was first read at the Midsummer Madness Fest sponsored by the Emory University Library staff on June 22,1988 , is a true masterpiece, which is reprinted below in its entirety (in a slightly abbreviated version) with the kind permission of her "agent" Laura Akerman, that we can only hope will not turn out to be Peabody's only library poem.

Good reading!

\section{College Library}

It is finals week;

they have come with

doom resonant frightened

eyes, voices that surprise

themselves, and too late.

They cannot be helped enough.

Anita Norman

(Copyrighted)

\section{Midsummer Eve}

or

Why on some occasions in the library

it sometimes occurs that

everything which appears to be in perfect order, isn't

'Twas quiet at the Library

that fine midsummer eve,

All was in good order.

(Library of Congress, I believe.)

Hours since the Librarian

had clicked off all the lights,

chucked the last dawdling patron out

and locked up for the night.

Midnight at the Library...

no quiet is quite so deep

as the breathless, dusty quiet

of a library asleep.

But Hark!...was that a rustling,

a shuffling in the dark?

The shelves began to tremble

there was no one there to hark...

For no one knew that suddenly (at precisely 12:05)

on that weird midsummer evening,

the collection was alive.

The shelves began to rattle as

the books began to hop,

they were straining at their bindings,

then down to the floor they plopped!

Treatises, tomes, and texts untouched since nineteen hundred and one

flapped their covers and shouted "Whoopee!" ...the madness had begun.

In horrifying disarray

they tumbled, slid and hobbled

a rumbling avalanche of books

on the lam and looking for trouble.

They were racing the booktrucks down the stairwell

to Circulation for laughs

and checking each other out just for the hell, those naughty monographs.

The maps unfurled, the atlases whirled, the globe did bumps and grinds, and the vol. l's were tangoing with the vol. 99's.

The audiotapes strip poker played with the films in various media. The dictionaries grew unafraid and wrestled the encyclopedia;

The copy l's and copy 2's were coupling in the carrels, their shamelessness producing added copies by the barrels...

The PN 6000's were swapping some smutty stories, all the whiles the phonograph records and microfilms were rolling in the aisles;

The pages were flying, the ink was flowing, it was war on the third floor, when the UA 30 battalion challenged the UG 44's.

On the roof, the HV6500s were jumping off the brink, while the nautical VM flotilla was launching itself into the sink;

The pious BF-BX's at first were a trifle uptight, until they commenced to convert one another, then Heavens! What a fight! 
For hours upon hours,

the ruction carried on;

from pillar to post they partied, until...

the crack of dawn!

And then the most amazing

event of all occurred...

They returned to their shelves and re-filed themselves

without a single word.

Every book found the final strength

to heave itself into the stacks.

(All but the littlest, tiniest book

which never made it back.)

Back in their place, with cunning grace,

they hid their traces well

though spines were broken and covers ripped

from the outside, none could tell.
And if to the depths of the elevator shaft they had swept a few pages or so, and if a few volumes were out of place, who would ever know?

'Twas morning at the Library.

The Librarian noted smugly

how each and every silent row

was tucked in nice and snugly.

And nary a soul would have guessed what befell

if it hadn't been for that wee

tiniest little book,

which whispered it all... to me!

\section{Beinecke Library fellowships}

The Beinecke Rare Book and Manuscript Library, Yale University, offers short-term fellowships to support visiting scholars pursuing postdoctoral or equivalent research in its collections. The fellowships, which support travel to and from New Haven, Connecticut, and pay a living allowance of $\$ 1,200$ per month, are designed to provide access to the library for scholars who reside outside the greater New Haven area. The length of a grant, normally one month, will depend on the applicant's research proposal; fellowships must be taken up between September 1990 and May 1991. Recipients are expected to be in residence during the period of their award and are encouraged to participate in the activities of Yale University.

Applicants should submit a resume and a brief research proposal (not to exceed three pages) to the Director, Beinecke Rare Book and Manuscript Library, Box 1603A Yale Station, New Haven, CT 06520-1603. The proposal should emphasize the relationship of the Beinecke collections to the project and state the preferred dates of residence. The applicant must also arrange to have two confidential letters of recommendation sent to the $\mathrm{Di}$ rector.

The following named fellowships will also be awarded: the FrederickW. Beinecke Fellowship in Western Americana; the Donald C. Gallup Fellowship in American literature; and the H.P. Kraus Fellowship in early books and manuscripts. There is no special application procedure for these named fellowships.
Application materials must be received by January 15, 1990. Awards will be announced in March 1990 for the period September 1990 through May 1991.

\section{NCLIS.Recognition Awards}

The U.S. National Commission on Libraries and Information Science is requesting nominations for the third year of annual awards to honor initiative in improving and promoting the nation's library and information services. The award program, established in 1987, recognizes the best initiative taken by an individual and by a non-governmental, non-library organization in improving and promoting library and information services in the previous calendar year. The NCLIS Recognition Awards will be pre sented in Washington, D.C., in spring 1990.

Nominees for the award must be American citizens or non-governmental, non-library organizations, including businesses, trade unions, charitable institutions, and voluntary associations or groups. The initiative to be considered must have been performed in the U. S. or its territories. Separate awards will be given-one for individuals and one for organizations.

Nomination forms and additional information are available from NCLIS, 1111 18th St., N.W., Suite 310 , Washington, DC 20036. The closing date for submission is January 15, 1990. 